\title{
Tracing the Path of Inhaled Nitric Oxide: Biological Consequences of Protein Nitrosylation
}

\author{
Vikram Bhatia $^{1}$, Lara Elnagary ${ }^{1}$, and Shyamala Dakshinamurti ${ }^{2}$ \\ ${ }^{1}$ University of Manitoba Children's Hospital Research Institute of Manitoba \\ ${ }^{2}$ University of Manitoba College of Medicine
}

July 13, 2020

\begin{abstract}
Nitric oxide (NO) is a comprehensive regulator of vascular and airway tone. Endogenous NO produced by nitric oxide synthases regulates multiple signaling cascades, including activation of soluble guanylate cyclase to generate cGMP, relaxing smooth muscle cells. Inhaled NO is an established therapy for pulmonary hypertension, especially in neonates, and has been recently proposed for treatment of hypoxic respiratory failure and acute respiratory distress syndrome due to COVID-19. In this review, we summarize the effects of endogenous and exogenous NO on protein S-nitrosylation, which is the selective and reversible covalent attachment of a nitrogen monoxide group to the thiol side chain of cysteine. This post-translational modification targets specific cysteines based on the acid/base sequence of surrounding residues, with significant impacts on protein interactions and function. S-nitrosothiol (SNO) formation is tightly compartmentalized and enzymatically controlled, but also propagated by non-enzymatic transnitrosylation of downstream protein targets. Redox-based nitrosylation and denitrosylation pathways dynamically regulate the equilibrium of SNO-proteins. We review the physiological roles of SNO proteins, including nitrosohemoglobin and autoregulation of blood flow through hypoxic vasodilation, and pathological effects of nitrosylation including inhibition of critical vasodilator enzymes; and discuss the intersection of NO source and dose with redox environment, in determining the effects of protein nitrosylation.
\end{abstract}

$=202$ word

In the respiratory tract, nitric oxide (NO) is produced by epithelial cells, inflammatory cells, airwayinnervating neurons and vascular endothelial cells ${ }^{1}$. It functions as a comprehensive physiological modulator, regulating airway and vascular tone by diffusion from epithelium and endothelium respectively toward smooth muscle; and contributes to immune responses, angiogenesis, hemostasis, neurotransmission, tissue repair and apoptosis $^{2}$. Nitric oxide synthase (NOS) catalyzes the conversion of L-arginine to L-citrulline generating NO, which in turn activates soluble guanylate cyclase (sGC), converting guanosine triphosphate (GTP) to 3',5'-cyclic guanosine monophosphate (cGMP) ${ }^{3}$.

Inhaled NO (iNO) is an established therapy for pulmonary hypertension, notably for persistent pulmonary hypertension of the newborn (PPHN), based on its primary action of increasing the vasodilator cGMP ${ }^{4}$.

NO is also described as having anti-Coronavirus activity in vitro ${ }^{5}$, inhibiting the viral replication cycle by interfering with RNA and protein synthesis ${ }^{6}$. iNO has recently been proposed for treatment of hypoxic respiratory failure in COVID-19, studied in 8 clinical trials currently enrolling patients per www.clinicaltrials.gov, some citing as high as 9 times the inhalational dose regularly used for PPHN treatment. In this context, we will review effects of endogenous as well as exogenous NO on protein S-nitrosylation, a post-translational modification arising from reaction with NO, with wide-ranging effects on protein biological activity.

\section{Nitric Oxide}


NO is a lipophilic gas capable of diffusing over a wide area $(100 \mu \mathrm{m})$, moving freely across membranes of neighboring cells to function as a short-lived, locally-acting physiological messenger ${ }^{7}$. In biological systems, tissue NO concentration ranges $10-100 \mathrm{nM}$, with a measured half-life of 3-5 seconds ${ }^{8}$. NO signaling can prove beneficial or harmful, depending on duration and local concentration of NO, and the cellular signaling pathways affected. Protein S-nitrosylation (proper chemical term is nitrosation; the term 'nitrosylation' is commonly used to describe the biological function of this modification) is both rapidly reversible and precisely targeted, where NO covalently attaches to the thiol, an organic sulfhydryl group containing a sulfur-hydrogen bond (-SH), on a cysteine amino acid to form a S-nitrosothiol $(\mathrm{SNO})^{9,10}$, a biologically active intermediate more stable than NO itself ${ }^{11}$. SNO can arise from endogenous or exogenous NO, from nitrite (exogenous or endogenous, usually derived from dietary nitrate) or other oxidized NO species, metal-NO complexes or protein nitrosothiols (R-SNOs) ${ }^{12}$.

NO exists as a free radical with one unpaired electron $\left({ }^{*} \mathrm{NO}\right)$ but without electrical charge. It is not very reactive at physiological concentrations, but can morph into different redox states (Figure 1 ); NO can lose electrons to become nitroso cation $\left(\mathrm{NO}^{+}\right)$or gain electrons to become nitroxyl anion $\left(\mathrm{NO}^{-}\right)^{13}$. $\mathrm{NO}^{+}$can react with a thiol group to nitrosylate a protein only if that protein is adjacent; $\mathrm{NO}^{+}$will promptly hydrolyze to nitrite in presence of water. In aerobic tissues, $\mathrm{NO}$ can be oxidized to nitrite $\left(\mathrm{NO}_{2}{ }^{-}\right)$or nitrate $\left(\mathrm{NO}_{3}{ }^{-}\right)$ anions, which are less biologically active; or further oxidized to the far more reactive species nitrogen dioxide $\left({ }^{*} \mathrm{NO}_{2}\right)$, dinitrogen trioxide $\left(\mathrm{N}_{2} \mathrm{O}_{3}\right)$, or peroxynitrite $\left(\mathrm{ONOO}^{-}\right)^{14} \cdot{ }^{*} \mathrm{NO}$ itself reacts slowly with a neutral thiol; but if that thiol is protonated to a thiyl radical $\left(\mathrm{RS}^{*}\right)$ by ${ }^{*} \mathrm{NO}_{2},{ }^{*} \mathrm{NO}$ will react with it very rapidly to form S-nitrosothiol ${ }^{15}$. This reaction is facilitated by presence of superoxide anion $\left(\mathrm{O}_{2}{ }^{-}\right)^{16}$. A reduced thiol (thiolate, $\mathrm{RS}^{-}$) can be nitrosylated by $\mathrm{N}_{2} \mathrm{O}_{3}$ formed by oxidation of $\mathrm{NO}$ oxidized by oxygen to $\mathrm{NO}_{2}$, then recombined with ${ }^{*} \mathrm{NO}$. Both $\mathrm{RS}^{-}$and $\mathrm{RS}^{*}$ will react with $\mathrm{ONOO}^{-}$, toxic product of ${ }^{*} \mathrm{NO}$ with $\mathrm{O}_{2}{ }^{-}$, resulting in S-nitrosothiol ${ }^{8}$. The redox environment around ${ }^{*} \mathrm{NO}$ becomes critical when ${ }^{*} \mathrm{NO}$ is in pharmacological concentrations, driving first order reactions that greatly promote S-nitrosothiol formation ${ }^{14}$.

\section{Cysteine S-Nitrosylation}

Cysteine is among the least abundant residues in proteins, but one of the most conserved ${ }^{17}$. It is functionally unique due to its highly reactive thiol side chain, which is nucleophilic, acidic and redox active ${ }^{18}$ due to the presence of hybrid orbitals, making electron transfer reactions more likely at the thiol group ${ }^{19}$. The frequency of cysteine residues is greater in transmembrane proteins $(3.5 \%)$ versus purely intracellular proteins $(1.6 \%)^{20}$, and more common in extracellular $(3.2 \%)$ than cytosolic domains $(1.0 \%)^{21}$. Cysteines play a principal structural role in the formation of disulfide bonds critical for correct protein folding ${ }^{22}$, promote catalysis by redox enzymes ${ }^{23,24}$, and regulate protein-protein interactions ${ }^{25}$.

Cysteine S-nitrosylation serves as a mediator of NO-related bioactivity, both in NOS-containing cells and following NO diffusion for intercellular signaling ${ }^{26}$. Over 3000 proteins are regulated by nitrosylation, impacting biological processes ranging from DNA damage repair, transcriptional regulation, cell growth, differentiation and apoptosis, to protein stability and redox regulation ${ }^{27}$. Dysregulated S-nitrosylation is implicated in a number of pathologies ${ }^{28-31}$.

Reversible thiol nitrosylation ${ }^{32,33}$ is not the only post-translational modification to which cysteines are susceptible. Others include glutathionylation ${ }^{34}$, carbonylation ${ }^{35}$, guanylation ${ }^{36}$ and sulfhydrylation ${ }^{37}$. Several of these can alter protein stability, hydrophobicity or protein-protein interactions; but only nitrosylation acts in a rapidly reversible manner suitable for cell signaling ${ }^{38-41}$. In this, nitrosylation shares similar properties with phosphorylation. Both modifications exhibit substrate specificity, and strict spatiotemporal regulation. However, while the specificity of serine/threonine phosphorylation is determined by kinase enzymes' selectivity for their protein targets, cysteine nitrosylation is unique in being largely non-enzymatic ${ }^{10}$.

\section{Nitrosothiols: Nitrosylation Substrates and Donors}

S-nitrosylated proteins (R-SNO) are formed by exposure of redox-active motifs to NO, by nitrosyl moieties transferred to the target cysteine from other proteins (termed protein-assisted transnitrosylation), or enzymatically through activity of S-nitrosylase or metalloprotein-catalyzed reactions ${ }^{42,43}$. In non-enzymatic 
transnitrosylation, the nitroso $\left(\mathrm{NO}^{+}\right)$group carried by a donor R-SNO is dropped onto an accessible target cysteine on a nearby protein with the correct surrounding amino acid configuration, creating a new R-SNO.

While $90 \%$ of all S-nitroso groups are anchored to cysteine residues of large proteins like albumin or hemoglobin, $10 \%$ involve low molecular weight proteins (eg cysteine/S -nitrosocysteine, glutathione/S nitrosoglutathione) which function as intermediates in transnitrosylation ${ }^{44}$. Transnitrosylation can create a cascade similar to a kinase signaling cascade, whereby one nitrosylation event triggers a next and a next. Not every cysteine in a protein can get S-nitrosylated. Nitrosylation is regulated by close protein interactions, and by the presence of "SNO motifs" marking a particular cysteine as a nitrosylation candidate: a sequence of adjacent amino acids consisting of nucleophilic residues (generally an acid and a base), which may result from the protein's tertiary or quaternary structure ${ }^{45}$. Proteomic analyses reveal nitrosylated cysteine residues sitting in a hydrophobic pocket, immediately flanked by acidic (Asp, Glu) and basic (Lys, Arg, His) amino acids ${ }^{46,47}$. The surrounding residues determine cysteine S-nitrosylation, by altering thiol nucleophilicity in that subcellular environment ${ }^{45}$. The presence of charged residues in the vicinity of a cysteine residue provides sites for protein-protein interfaces that direct the S-nitrosylation of that cysteine ${ }^{48}$. This protein micro-environment guides site-specific transnitrosylation; there is little overlap between these nitrosylatable cysteines, and those cysteines targeted by other redox-dependent or enzymatic modifications ${ }^{10}$. The propensity for nitrosylation of a given cysteine can be predicted by computational analysis of the surrounding amino acid sequence ${ }^{49}$.

The nature of the $\mathrm{R}$ determines R-SNO chemistry, as R-SNOs vary in their stability ${ }^{50,51}$. CysNO (nitrosocysteine) structure exhibits different characteristics than HSNO (thionitrous acid, the smallest possible R-SNO); S-nitrosoglutathione (GSNO), slightly larger, is more stable ${ }^{52,53}$. S-nitrosothiols can transnitrosylate thiol-containing amino acids, peptides, or proteins by releasing $\mathrm{NO}^{+}$or $\mathrm{NO}^{-}$, more rapidly than they can spontaneous release $\mathrm{NO}^{13}$. The nitroso group can also move from stable S-nitrosoproteins to less stable species such as $\mathrm{CysNO}^{54,55}$, which in turn can non-enzymatically decompose to cysteine and an NO radical $^{54,56}$.

\section{Regulators of Denitrosylation: GSNO and Thioredoxin}

Turnover of the cellular pool of NO reflects the balance between protein nitrosylation triggered by NO, and the enzymatic denitrosylation of S-nitrosylated proteins ${ }^{57,58}$. The cellular balance of protein transnitrosylation to denitrosylation can be determined by an equilibrium between glutathione to nitrosoglutathione, thioredoxin to thioredoxin reductase, or other intracellular SNO carriers ${ }^{59}$ (Figure 2 ).

S-nitrosoglutathione (GSNO) is the most physiologically relevant R-SNO in the respiratory system ${ }^{60}$. Its nitrosylation state is regulated by GSNO reductase (GSNOR), an evolutionary conserved, ubiquitous NADHdependent alcohol dehydrogenase enzyme ${ }^{61,62}$. GSNOR metabolizes GSNO to oxidized glutathione plus a glutathione N-hydroxysulfenamide intermediate, which is ultimately reduced to ammonia ${ }^{44}$.

Denitrosylation of nitrosylated proteins is catalyzed by reduced glutathione (GSH) which takes the nitroso group to become GSNO, leaving free - SH groups on denitrosylated cysteine residues. GSNO is a substrate for GSNOR, which reverts it GSH ${ }^{61}$. Since GSNO is thus in equilibrium with other S-nitrosylated proteins, increased levels of GSNOR indirectly regulates the cellular level of S-nitrosylated proteins, by promoting GSNO denitrosylation ${ }^{63}$. Pharmacological inhibition or genetic deletion of GSNOR leads to enhanced systemic vasodilation ${ }^{64,65}$, and GSNOR-null mice have increased blood levels of S-nitrosylated proteins ${ }^{44}$. That GSNOR deletion is associated with decreased systemic vascular resistance is consistent with a proposed role for GSNO in conveying the activity of pulmonary eNOS-derived NO to the systemic circulation ${ }^{19}$. On the other side of the equation, an imbalance in the cellular redox state that increases superoxide ion and peroxynitrite promotes S-nitrosylation, by decreasing levels of reduced $\mathrm{GSH}^{66,67}$.

The other major regulator of the cellular protein thiol redox state is thioredoxin (Trx), a ubiquitously conserved oxidoreductase which limits protein nitrosylation ${ }^{68,69}$. In contrast to GSNOR's strict substrate specificity for GSNO, cytosolic and mitochondrial thioredoxins directly mediate the denitrosylation of diverse R-SNO protein substrates ${ }^{19}$. Thioredoxin's Cys-X-X-Cys active site ${ }^{70}$ tackles denitrosylation as a multi- 
step process: (i) the nucleophilic cysteine displaces NO from the R-SNO's cysteine by heterolytic cleavage, resulting in formation of a mixed disulfide bridge between thioredoxin and its target substrate, (ii) HNO is released, (iii) the second reactive cysteine resolves the disulfide bridge, forming an oxidized variant of thioredoxin and releasing the now reduced substrate, and (iv) the thioredoxin active site is finally reduced by thioredoxin reductase $(\operatorname{TrxR})^{71,72}$. Target R-SNO proteins can also directly transnitrosylate one of thioredoxin's active site cysteines, causing release of $\mathrm{HNO}^{73}$. Thioredoxin plays an active role in attenuating NO signaling as well as in ameliorating nitrosative stress. NO can reciprocally modulate the redox activity of thioredoxin, by nitrosylating thioredoxin itself $^{74}$.

\section{Endogenous NO and Compartmentalized Nitrosylation}

Generation of intracellular NO is tightly linked to oxygen homeostasis ${ }^{75}$, primarily by nitric oxide synthase (NOS) enzymes ${ }^{76}$. The three isoforms of NOS in mammalian cells include neuronal NOS (nNOS; NOS1), inducible NOS (iNOS; NOS2) and endothelial NOS (eNOS; NOS3). Endogenous NO is produced by NOS from its substrate L-arginine ${ }^{27,77}$. NOS isoform expression differs across organs, tissues, cells, or subcellular compartments. eNOS and nNOS are constitutively expressed, stimulated by intracellular calcium. nNOS is found in neurons, also in kidney, liver, gut and lung ${ }^{78}$. Calcium-insensitive iNOS is induced during the inflammatory response, contributing to the respiratory burst of phagocytes ${ }^{79}$. eNOS is induced in endothelium by exercise and sheer stress ${ }^{78}$, and by chronic hypoxia ${ }^{80}$, which also upregulates eNOS's chaperone heat-shock protein Hsp90, calcium-independently stabilizing the NO output of eNOS ${ }^{81}$. Smooth muscle also expresses eNOS, though not generating NO in physiologically important amounts ${ }^{82}$.

At physiological levels of NO, endogenous SNO concentrations are in the low micromolar range ${ }^{60,83-85}$. Inducible NOS generates higher local concentrations of NO than do other NOS isoforms. A high local NO concentration, in presence of oxygen, is thought to be required for S-nitrosylation of proteins ${ }^{86,87}$, though lower NO levels may be sufficient where S-nitrosylation involves reactions between NO and thiyl radicals or is catalyzed by transition metals ${ }^{88,89}$. Each NOS isoform can also be S-nitrosylated, which down-regulates their activity ${ }^{90,91}$. NO-mediated nitrosylation of eNOS is followed by transnitrosylation of eNOS regulators including Hsp90 ${ }^{92}$, inhibiting the activation of eNOS in a negative feedback mechanism limiting production of additional NO.

Though NO is freely diffusible, its concentration due to compartmentalization of NOS creates localized environments conducive to the S-nitrosylation of specific proteins. The physical proximity of SNO targets to NOS favors interaction between NOS enzymes and their nitrosylation substrate, directly or through scaffolding proteins ${ }^{93}$. In endothelial cells, nitrosylation target proteins are typically found in close proximity to eNOS, to promote their S-nitrosylation ${ }^{94}$; the NO generated by eNOS remains within its subcellular region, confining S-nitrosylation to those proteins adjacent ${ }^{95}$. eNOS is found in the Golgi body, generating a local NO pool that enhances nitrosylation of proteins within the Golgi; and in membrane caveolae where nitrosylation may regulate receptor signaling complexes ${ }^{96}$. S-nitrosylation of proteins in the Golgi reduces granule trafficking from Golgi body to plasma membrane ${ }^{96}$. The eNOS located at the plasmalemma is efficiently activated by calcium-dependent or Akt-dependent agonists, while eNOS on the Golgi body is less responsive to agonists. Consequently, eNOS at membrane caveolae releases a greater amount of NO, compared to eNOS in Golgi ${ }^{97,98}$. Caveolar eNOS also colocalizes with cortical actin filaments, so eNOS activation can respond to mechanical stimuli such as sheer stress; actin depolymerization or cytoskeletal reorganization can alter eNOS activity and thus alter nitrosylation of caveolar proteins ${ }^{99}$. There is also selectivity of cysteine targeting among NOS isoforms; different NOS isoforms can bind to different regions of the same target protein, resulting in S-nitrosylation of multiple cysteine residues ${ }^{100}$. This profound localization of effect in the case of endogenous NO permits the targeted nitrosylation of proteins within subcellular compartments, spatially and temporally associated with NOS activation. Such fine target control is not reported when discussing exogenous sources of NO, which may cause nitrosylation of proteins in many cell types or cell compartments in the course of their pharmacological action.

\section{Nitrates and Nitrites Generating NO}


Nitrites elicit physiological responses reminiscent of free NO, including vasodilation and inhibition of platelet aggregation, resulting in their therapeutic use as NO donors. Nitroglycerin, its long acting congener isosorbide dinitrate, and sodium nitroprusside (SNP) are commonly used NO-releasing drugs for treatment of systemic hypertension and coronary artery disease. SNP releases NO rapidly without need of enzymatic catalysis, while nitroglycerin releases $\mathrm{NO}$ with the aid of mitochondrial aldehyde dehydrogenase ${ }^{101}$. Nitrite anion $\left(\mathrm{NO}_{2}{ }^{-}\right)$is reduced by circulating or tissue bound nitrite oxidoreductases to create a stable, nonreactive pool of NO, and contributing thence to SNO formation. Nitrite reductase is potentiated by hypoxia, so endogenous $\mathrm{NO}_{2}{ }^{-}$is promptly reduced to $\mathrm{NO}$ if tissue oxygen levels decrease, resulting in protective vasodilation ${ }^{102}$.

In adults, the majority of circulating $\mathrm{NO}_{2}^{-}$is derived from dietary nitrate $\left(\mathrm{NO}_{3}{ }^{-}\right)$, while in neonates, nutritional sources are poor in $\mathrm{NO}_{3}{ }^{-103}$ resulting in lower conversion to $\mathrm{NO}_{2}{ }^{-104}$ and thus greater dependence on NOS to generate NO. Serum nitrite levels are significantly lower in infants with or without pulmonary hypertension, compared with adults ${ }^{104}$. Treatment with inhaled ethyl (alkyl) nitrite, a volatile $\mathrm{NO}_{2}{ }^{-}$donor, is an effective acute pulmonary vasodilator in $\mathrm{PPHN}^{105}$, and prevents hyperoxia-induced lung injury in neonatal rats at least as well as inhaled $\mathrm{NO}^{106}$. Systemic or inhaled sodium nitrite $\left(\mathrm{NaNO}_{2}\right)$ is an alternative $\mathrm{NO}_{2}{ }^{-}$based therapy with relatively potent pulmonary vasodilator effect in the setting of experimental models of chronic hypoxic pulmonary hypertension ${ }^{107,108}$. Nebulized $\mathrm{NaNO}_{2}$ acutely reduces pulmonary vascular resistance in pulmonary hypertensive patients with $\beta$-thalassemia ${ }^{109}$. In chronically hypoxic rat pups, subcutaneous $\mathrm{NaNO}_{2}$ increases tissue $\mathrm{NO}$, ameliorating pulmonary hypertension comparably to inhaled NO, while also increasing R-SNO content in the lung ${ }^{110}$. $\mathrm{NaNO}_{2}$ increases lung $\mathrm{NO}$ and SNO contents to a greater extent than does inhaled $\mathrm{NO}$, albeit without causing protein nitration ${ }^{111-113}$. Nebulized $\mathrm{NO}_{2}{ }^{-}$ inhibits hypoxic pulmonary vasoconstriction without decreasing pulmonary arterial pressure or improving oxygenation; in contrast, nebulization of acidified forms of $\mathrm{NaNO}_{2}$ induce higher levels of $\mathrm{NO}$ and thus have greater vasodilator effects than $\mathrm{NO}_{2}{ }^{-}$alone ${ }^{114}$, suggesting it is the $\mathrm{NO}$ release and not simply the SNO formation that is the causative agent for $\mathrm{NaNO}_{2}$-triggered vasodilation. Nebulization of L-cysteine during treatment with nitric oxide increases formation of circulating S-nitrosocysteines without further increasing pulmonary vasodilation ${ }^{115}$, supporting the theory that SNO is not itself a pulmonary vasodilator.

\section{Exogenous NO}

Exogeneous NO is delivered to the lungs by titrated inhalation (iNO), or to the systemic circulation by vasoactive nitrites. Most current treatment regimens use iNO doses up to 20ppm, considered a relatively safe range; clinically apparent toxicity, primarily methemoglobinemia, has been observed at doses above 80ppm. However toxicities at a cellular level, including protein nitration or nitrosylation, are reported at lower doses ${ }^{116}$. Toxicity is dose-dependent and augmented during oxidative stress. Nitrogen dioxide $\left({ }^{*} \mathrm{NO}_{2}\right)$, the reactive NO derivative more directly toxic to the lung, can reach a concentration of 5ppm within 12 min during treatment with $20 \mathrm{ppm}$ iNO in $100 \% \mathrm{O}_{2}$, and at $80 \mathrm{ppm}$ iNO within 3 min; while in $21 \% \mathrm{O}_{2}$ this reaction takes more than 1 hour ${ }^{117}$. The use of continuous-flow ventilation circuits has largely eliminated toxic ${ }^{*} \mathrm{NO}_{2}$ accumulation within the airways during iNO treatment, though there has been some concern about gas stasis in distal airways during use of high-frequency modes ${ }^{118}$.

The interaction between the oxidative environment and iNO determines the nature of its downstream nitrosative chemistry (Figure 1 ). Alone, oxygen toxicity is known to manifest as protein tyrosine nitration, largely due to the action of $\mathrm{ONOO}^{-}$. Nitrotyrosine can lead to enzyme inactivation and also accelerate protein degradation ${ }^{119}$. This finding has been well described in hyperoxia models of bronchopulmonary dysplasia ${ }^{120}$. However a shift occurs, when iNO is introduced, in the balance between protein nitration and nitrosylation. Exposure to $80 \% \mathrm{O}_{2}$ rapidly induces both tyrosine nitration and cysteine nitrosylation. Increase to $95 \% \mathrm{O}_{2}$ selectively increases nitration, disfavouring nitrosylation; but addition of 20ppm iNO limits the increase in nitrotyrosine while enhancing formation of S-nitrosocysteine ${ }^{121}$. This is ascribed to the excess NO reacting with $\mathrm{ONOO}^{-}$to produce ${ }^{*} \mathrm{NO}_{2}$ and $\mathrm{NO}_{2}^{-}$, resulting in decreased $\mathrm{ONOO}^{-}$available for reaction with tyrosine. If tyrosine nitration were taken as the primary cause of tissue injury, this would imply iNO decreases the toxicity of hyperoxia ${ }^{122}$; and indeed very high doses of iNO are reported to mitigate the lethality of $95 \%$ 
$\mathrm{O}_{2}$ exposure $^{123}$. Nitrosocysteine toxicity, if present, needs to be accounted for separately. Administration of high dose NO with hyperoxia causes inflammation and surfactant dysfunction, relieved by coadministration of superoxide dismutase, suggesting that nitrosocysteine toxicity is present ${ }^{124}$.

After iNO administration, regardless of concurrent oxygen tension, nitrosylation is the primary protein modification seen in airway and alveoli ${ }^{125}$. An oxygen-rich environment is required for SNO formation; anaerobic solutions of $\mathrm{NO}$ are not capable of nitrosylating cysteine or glutathione, but will do so if $\mathrm{O}_{2}$ is present with $\mathrm{NO}^{126}$. NO autooxidation to $\mathrm{N}_{2} \mathrm{O}_{3}$ follows second order kinetics, but where $\mathrm{NO}$ is in pharmacological quantities, this process may be sufficient to promote R-SNO formation ${ }^{127}$. The fate of exogenous NO further depends on the rate of combination of $\mathrm{NO}$ with reactive oxygen species. $\mathrm{NO}$ reacts readily with $\mathrm{O}_{2}{ }^{-}$to form $\mathrm{ONOO}^{-}$, which will induce thiol nitrosylation; but in vivo the reactivity of $\mathrm{ONOO}^{-}$is dramatically modified by its rapid reaction with $\mathrm{CO}_{2}$ which abolishes its nitrosative efficiency ${ }^{128}$. Contemporaneous generation of $\mathrm{NO}$ and $\mathrm{O}_{2}^{-}$results in 100-fold more efficient generation of $\mathrm{SNO}$ than does $\mathrm{ONOO}^{-}$, via a $\mathrm{ONOO}^{-}$independent, $\mathrm{CO}_{2}$-insensitive mechanism ${ }^{129}$. SNO formation is linear as NO concentration increases; but when the concentration of $\mathrm{O}_{2}{ }^{-}$approaches equimolar with $\mathrm{NO}$, SNO formation increases exponentially ${ }^{127}$. Higher concentrations of $\mathrm{NO}$ inhibit direct lipid peroxidation by $\mathrm{ONOO}^{-}$, suggesting $\mathrm{NO}$ draws $\mathrm{O}_{2}{ }^{-}$into other reactions rather than generating $\mathrm{ONOO}^{-130}$; the preferential formation of SNO is imputed. Neither $\mathrm{ONOO}^{-}$nor $\mathrm{O}_{2}{ }^{-}$freely diffuse across membranes, as they encounter an energetic barrier at the hydrophobic lipid bilayer, though they can traverse cell membranes via anion channels ${ }^{131}$. Under physiological conditions this would effectively compartmentalize SNO formation; but not in presence of an excess of diffusible iNO.

$\mathrm{O}_{2}{ }^{-}$formation is a hallmark both of hyperoxic and hypoxic pulmonary environments, in the former case formed directly from $\mathrm{O}_{2}{ }^{132}$, and in the latter due to respiratory uncoupling ${ }^{133}$ and nitrative inhibition of superoxide dismutase ${ }^{134}$. Thiol oxidation increases as hypoxia worsens and cytosolic ROS stress increases ${ }^{135}$. Acute hypoxia is sufficient to increase endothelial cell protein nitrosylation ${ }^{136}$. A decrease in local superoxide dismutase activity decreases bioavailability of $\mathrm{NO}$ in the microcirculation ${ }^{137}$. As iNO is usually administered to hypoxemic patients, in combination with therapeutic high oxygen concentrations, it can be assumed that under both circumstances, the reaction kinetics of $\mathrm{NO}$ with $\mathrm{O}_{2}{ }^{-}$described above would drive nitrosothiol formation more than any other post-translational modification.

\section{NO and Hypoxic Vasodilation: Nitrate Reduction or Nitrosylation of Hemoglobin?}

Nitrosothiol formation may be viewed as a beneficial modification, largely because of its putative role in mediating hypoxic vasodilation, which couples tissue oxygen delivery to metabolic demand. The circulation of oxygenated hemoglobin to a hypoxic tissue results in dissociation of oxygen from hemoglobin, but also triggers localized vasodilation, increasing blood flow. Two mechanisms have been proposed: that oxygenated blood carries SNO as a NO equivalent, and upon deoxygenation, nitrosohemoglobin releases a nitrosylated intermediate which is exported from red blood cells to the plasma as a low-molecular-weight R-SNO, leading to hypoxic vasodilation ${ }^{138}$; and/or that $\mathrm{NO}_{2}{ }^{-}$is the circulating $\mathrm{NO}$ reservoir, and deoxyhemoglobin acts as a nitrite reductase, producing from $\mathrm{NO}_{2}{ }^{-}, \mathrm{NO}$ and $\mathrm{N}_{2} \mathrm{O}_{3}$, which cause vasodilation ${ }^{139}$. Both hypotheses arise from observations of arteriovenous gradients, in case of the SNO-Hb hypothesis a gradient of nitrosohemoglobin, with an increase in plasma S-nitrosothiols in the venous circulation ${ }^{140}$; and in case of the nitrate hypothesis, the arterial to venous decline of plasma $\mathrm{NO}_{2}^{-}$, due to its consumption ${ }^{141}$.

In the SNO-Hb paradigm, when oxygen is bound to hemoglobin molecules in the lungs, the conformational change of the beta subunit permits NO reaction with cysteine, forming S-nitrosohemoglobin. Upon delivery of oxygen to the tissues, deoxygenation of hemoglobin is accompanied by release of the NO group. Dissociation of nitrosohemoglobin results in the measurable formation of R-SNO in distal locations, including airway, gut and extracellular spaces $33,60,88,142,143$. While most R-SNO are membrane-impermeable, vasodilatory signaling occurs intracellularly. So R-SNOs may decompose to release free NO, either spontaneously or via catalysis by cell surface protein disulfide isomerase ${ }^{144,145}$, allowing NO diffusion into the cell. Alternatively, circulating R-SNO can transnitrosylate $\mathrm{H}_{2} \mathrm{~S}$ to generate membrane-permeable $\mathrm{HSNO}^{146}$; or similarly CysNO, or GSNO hydrolysis to CysNO-glycine, which enter cells via the L-type amino acid transporter ${ }^{147,148}$ or dipeptide transporter ${ }^{149}$ respectively. By facilitating transfer of $\mathrm{NO}$ in the nitroso form, hemoglobin functions 
as a physiological sensor of local oxygen tension, directly modulating local blood flow and oxygen delivery. S-nitrosohemoglobin contracts blood vessels, decreasing cerebral perfusion; however, where the transported NO is released, vessels relax and blood flow improves ${ }^{150}$.

In the nitrite paradigm, while the degree of hypoxia and acidosis required for $\mathrm{NO}_{2}{ }^{-}$reduction by xanthine oxidoreductase, and the high concentration of $\mathrm{NO}_{2}{ }^{-}$required to drive this reaction, initially made $\mathrm{NO}_{2}{ }^{-}$an unlikely intrinsic vasodilator, its ready intravascular reduction by deoxyhemoglobin reinstated it as a prime candidate for the transduction of $\mathrm{NO}$ vasodilator activity to tissues ${ }^{139}$. Deoxymyoglobin in skeletal muscle also is an abundant nitrite reductase ${ }^{151}$ while plasma ceruloplasmin acts as a nitrite synthase, oxidizing $\mathrm{NO}$ to $\mathrm{NO}_{2}{ }^{-152}$. As a potential storage pool for $\mathrm{NO}$, there is a lot more nitrite available; circulating levels of $\mathrm{NO}_{2}{ }^{-}$range $150-1000 \mathrm{nM}$, while circulating plasma nitrosothiols are estimated under $10 \mathrm{nM}^{139}$. This view gained ground after mutation of the conserved Cys93 residue of hemoglobin showed no loss of red blood celldependent hypoxic vasodilation ${ }^{153}$. Alleviation of pulmonary hypertension and attenuation of remodeling following nitrite inhalation in hypoxic animal ${ }^{154}$ and human subjects ${ }^{155}$ support this hypothesis. However an arterial infusion of $\mathrm{NO}_{2}{ }^{-}$produces no increase in blood flow, while eNOS activation by acetylcholine dose-dependently increases venous $\mathrm{NO}_{2}{ }^{-}$levels while augmenting local blood flow, suggesting the measured $\mathrm{NO}_{2}{ }^{-}$may be an indicator of endogenous $\mathrm{NO}$ but not itself act as a vasodilator ${ }^{156}$.

SNO-Hb and nitrite paradigms are not mutually exclusive hypotheses, but one may predominate in physiological conditions. A recent elegant defense of the SNO-Hb paradigm paints a picture of respiration and blood flow autoregulation as a balancing act of three gases: oxygen, $\mathrm{CO}_{2}$ and $\mathrm{NO}^{157}$, where intracellular nitrosothiols transduce the activity of NO to permit red blood cells to autoregulate blood flow for gas exchange. Stored blood is deficient in nitrosohemoglobin, impairing oxygen delivery by transfused red cells; this is restored when its hemoglobin is renitrosylated ${ }^{158}$. In the pulmonary circulation, SNO-Hb is purported to influence ventilation perfusion matching; exposure to sustained hypoxia causes a build-up of heme-nitrosyl species unable to proceed to the oxygen-requiring step of thiol nitrosylation, resulting in local pulmonary vasoconstriction ${ }^{159}$. Experimental inhalation of O-nitrosoethanol, a gas that induces nitrosothiol formation without releasing $\mathrm{NO}$ or $\mathrm{NO}_{2}{ }^{-}$, restores hemoglobin nitrosylation, and also pulmonary vasodilation ${ }^{160}$.

Transnitrosylation of hemoglobin depends on local NO and oxygen concentrations, and the ratio of NO to hemoglobin. In physiological concentrations, NO preferentially nitrosylates hemoglobin thiols or reacts with $\mathrm{O}_{2}^{-}$(prevented within red cells by their efficient superoxide dismutase activity), rather than being oxidized to $\mathrm{NO}_{2}{ }^{-161}$. Certain other nitroso donors are possible; among small R-SNOs, CysNO can access the buried cysteine residue in hemoglobin, while GSNO is too large to transnitrosylate hemoglobin ${ }^{162}$. $\mathrm{NO}_{2}{ }^{-}$ can nitrosylate hemoglobin as well ${ }^{62}$. In absence of oxygen, the NO bound to hemoglobin is released as $\mathrm{NO}^{-}$, resulting in methemoglobin. Under homeostatic $\mathrm{O}_{2}$ conditions, if the $\mathrm{NO}: \mathrm{Hb}$ ratio exceeds physiologic, nitrosylation of hemoglobin paradoxically decreases, while methemoglobin increases, particularly of deoxyhemoglobin. At high NO concentrations, $\mathrm{NO}$ will reduce methemoglobin to generate $\mathrm{NO}_{2}{ }^{-}$, without increasing nitrosohemoglobin ${ }^{163}$. Thus, the effects of endogenous $\mathrm{NO}$ and exogenous $\mathrm{NO}$ on beneficial hemoglobin nitrosylation cannot be assumed to be identical; more is not always better.

\section{Consequences of Protein Nitrosylation}

Endogenous nitrosylation may activate or inhibit protein activity. It is often difficult to discern whether nitrosylation of a specific protein is protective or dangerous, as cumulatively measured SNO does not change while the nitroso group is swapped from protein to protein. S-nitrosylation of thioredoxin is reported to decrease apoptotic signal in endothelial cells ${ }^{39}$. But a complex dynamic reveals that while cytosolic caspase-3 indeed rests in a state of denitrosylation due to its transnitrosylation of thioredoxin, maintaining homeostasis, mitochondrial caspase-3 denitrosylation, also by means of thioredoxin transnitrosylation, triggers caspasemediated apoptosis ${ }^{71}$. Also in endothelial cells, constitutive S-nitrosylation of NADPH subunit p47phox limits $\mathrm{O}_{2}{ }^{-}$production ${ }^{164}$; but increased nitrosylation of arginase triggers uncoupling of eNOS and worsens oxidative stress ${ }^{165}$. Nitrosylation can alter receptor stability or turnover, altering airway and vascular smooth muscle responses. S-nitrosylation of GRK2 inhibits interaction of GRK2 with adrenergic receptors, preventing receptor phosphorylation and internalization ${ }^{166}$. This averts tachyphylaxis and potentiates responses to 
adrenergic agonists, both constrictor and dilator. On the other hand, nitrosylation of dynamin promotes receptor internalization ${ }^{167}$. Protective effects of endothelial protein nitrosylation include nitrosylation of cell surface tissue plasminogen activator, increasing antiplatelet or fibrinolytic properties ${ }^{168}$ and inhibiting neutrophil adherence to the endothelial surface ${ }^{169}$. Low dose iNO prevents apoptosis in endothelial cells subject to VEGF receptor blockade ${ }^{170}$, and decreases fibrin deposition following hyperoxic injury ${ }^{171}$.

Excess nitrosylation carries negative consequences. In septic shock, hypotension and organ dysfunction is associated with iNOS induction and widespread protein nitrosylation, while reversal of nitrosylation improves blood pressure and mortality ${ }^{172}$. Reduction of cardiomyocyte protein S-nitrosylation by the enzyme GSNOR reverses septic myocardial depression ${ }^{173}$. GSNOR-null mice have a global increase in S-nitrosylated proteins, develop systemic hypotension under anesthesia and have higher mortality in sepsis ${ }^{44}$. During brain reperfusion after hypoxic ischemia, nitrosylation of the survival regulator PTEN increases, worsening brain injury; this is ameliorated by NOS inhibition ${ }^{174}$.

Within the lung, iNO in presence or absence of hyperoxia causes rapid protein nitrosylation in airway epithelium and alveolar interstitium, and also in vascular endothelium ${ }^{125}$. In endothelium, eNOS is abruptly inhibited by its own nitrosylation ${ }^{175}$, and by nitrosylation of Hsp90, in presence of exogenous $\mathrm{NO}^{92}$. While iNO triggers nitrosylation of cysteine to CysNO in alveolar lining fluid ${ }^{115}$, the transmembrane passage of that CysNO to facilitate transnitrosylation of hemoglobin is mediated by the L-amino acid transporter, which is impaired by hyperoxia, resulting in diminished NO effect ${ }^{176}$. CysNO corralled within the alveolar space can cause local damage. Surfactant protein-D, when nitrosylated, becomes a chemoattractant triggering inflammatory signaling ${ }^{177}$. Epithelial $\mathrm{Na}+$ channels $(\mathrm{ENaC})$, critical for regulating alveolar fluid, are inhibited by nitrosylation causing pulmonary edema ${ }^{178}$.

Following vascular smooth muscle challenge with CysNO, proteins identified by mass spectrometry as targets of S-nitrosylation are localized to cytoskeleton and ER/Golgi transport system, regulating protein folding, signal transduction, proliferation and apoptosis ${ }^{46}$. S-nitrosylation inhibits the RhoA pathway, thereby downregulating myosin phosphorylation ${ }^{179}$. However, an important deleterious effect of excess nitrosylation in vascular smooth muscle is guanylate cyclase inhibition (Figure 3 ). Soluble guanylate cyclase (sGC) acts as the intracellular receptor for NO, generating cGMP from GTP, thereby activating downstream cGMPdependent protein kinase (PKG) and promoting vasorelaxation. Its GTP catalytic site is a heterodimer of sGC $\alpha_{1}$ and $\beta_{1}$ subunits, each containing a heme- $\mathrm{NO} / \mathrm{O}_{2}$ binding domain ${ }^{180}$. When NO encounters a free $\beta_{1}$ subunit, it triggers the insertion of a heme moiety, then dissociation of the $\beta$ subunit from its chaperone Hsp90 and assembly of the sGC $\alpha_{1} / \beta_{1}$ catalytic unit ${ }^{181}$. sGC contains over 30 conserved cysteines, of which Cys122 in $\beta$ subunit, and Cys243, Cys516 in $\alpha$ subunit, are identified by mutational analyses as nitrosylation candidates ${ }^{182,183}$; nitrosylation of any one of these cysteines desensitizes sGC activity to NO stimulation. sGC nitrosylation is known to occur during iNO therapy ${ }^{184}$ and during treatment with nitrates ${ }^{185}$, inhibiting sGC catalytic activity and causing NO resistance ${ }^{186,187}$. sGC nitrosylation is modulated by the thioredoxin system; inhibition of thioredoxin reductase causes increased S-nitrosylation of cellular proteins including $\mathrm{sGC}^{188}$, resulting in the loss of NO-mediated arterial relaxation ${ }^{189}$. This finding is not unique to exogenous NO treatment; vascular smooth muscle in angiotensin-mediated hypertension ${ }^{183}$ and asthmatic bronchial smooth muscle ${ }^{190}$, both conditions marked by increased endogenous NO, are complicated by a nitrosylated, desensitized sGC, unresponsive to NO. Therapeutic developments to reactivate a nitrosylation-damaged sGC include cinaciguat (BAY 58-2667) ${ }^{191}$ and BAY 60-2770 ${ }^{192}$, which act as heme-mimetics to restore NOsensitivity of the sGC $\beta$ subunit; or riociguat (BAY 63-2521) ${ }^{193}$ and BAY 41-2272 ${ }^{186}$ that both enhance the sGC response to endogenous NO, and confer NO-independent allosteric activation of sGC. We have reported nitrosylation causing inhibition of the congener vasodilator, adenylyl cyclase, in pulmonary artery smooth muscle following hypoxia, and following exposure to $\mathrm{CysNO}^{194}$; candidate cysteine residues for nitrosylation are found at the activation interface of adenylyl cyclase with Gas ${ }^{195}$. It is possible that excess cysteine nitrosylation affects both major smooth muscle relaxant pathways by similar mechanisms, interfering with enzyme activation.

In sum, cysteine nitrosylation is a homeostatic amplifier of NO-mediated vasodilation, a protector from toxic 
protein nitration, and also a threat to alveolar integrity and NO-mediated vasodilation, about which one cannot be cavalier. When treating hypoxic respiratory failure with therapeutic hyperoxia and inhaled NO, side effects involving protein nitrosylation, notably in alveoli and bronchial or pulmonary arterial smooth muscle, can seriously interfere with treatment effects. As higher doses of NO are used, and as we learn more about the complex redox environment that governs localized nitroso group formation, more research is required on the boundaries between beneficial protein nitrosylation, and excess or hazardous nitrosylation.

\section{References}

1. Barnes PJ, Belvisi MG. Nitric oxide and lung disease. Thorax. 1993;48(10):1034-1043.

2. Ignarro LJ, Buga GM, Wood KS, Byrns RE, Chaudhuri G. Endothelium-derived relaxing factor produced and released from artery and vein is nitric oxide. Proc Natl Acad Sci U S A. 1987;84(24):9265-9269.

3. Arnold WP, Mittal CK, Katsuki S, Murad F. Nitric oxide activates guanylate cyclase and increases guanosine 3':5'-cyclic monophosphate levels in various tissue preparations. Proc Natl Acad Sci U S A. 1977;74(8):3203-3207.

4. Steinhorn RH. Nitric oxide and beyond: new insights and therapies for pulmonary hypertension. Journal of perinatology : official journal of the California Perinatal Association. 2008;28 Suppl 3(Journal Article):S6771.

5. Keyaerts E, Vijgen L, Chen L, Maes P, Hedenstierna G, Van Ranst M. Inhibition of SARS-coronavirus infection in vitro by S-nitroso-N-acetylpenicillamine, a nitric oxide donor compound. Int $J$ Infect Dis. 2004;8(4):223-226.

6. Akerstrom S, Mousavi-Jazi M, Klingstrom J, Leijon M, Lundkvist A, Mirazimi A. Nitric oxide inhibits the replication cycle of severe acute respiratory syndrome coronavirus. $J$ Virol. 2005;79(3):1966-1969.

7. Lancaster JR, Jr. A tutorial on the diffusibility and reactivity of free nitric oxide. Nitric Oxide.1997;1(1):18-30.

8. Czapski G, Goldstein S. The role of the reactions of .NO with superoxide and oxygen in biological systems: a kinetic approach. Free Radic Biol Med. 1995;19(6):785-794.

9. Qin Y, Dey A, Daaka Y. Protein s-nitrosylation measurement. Methods Enzymol. 2013;522:409-425.

10. Gould N, Doulias PT, Tenopoulou M, Raju K, Ischiropoulos H. Regulation of protein function and signaling by reversible cysteine S-nitrosylation. J Biol Chem.2013;288(37):26473-26479.

11. Stamler JS, Hess DT. Nascent nitrosylases. Nat Cell Biol. 2010;12(11):1024-1026.

12. Foster MW, McMahon TJ, Stamler JS. S-nitrosylation in health and disease. Trends in molecular medicine. 2003;9(4):160-168.

13. Arnelle DR, Stamler JS. NO+, NO, and NO- donation by S-nitrosothiols: implications for regulation of physiological functions by S-nitrosylation and acceleration of disulfide formation. Arch Biochem Biophys. 1995;318(2):279-285.

14. Kovacs I, Lindermayr C. Nitric oxide-based protein modification: formation and site-specificity of protein S-nitrosylation. Frontiers in plant science. 2013;4:137.

15. Madej E, Folkes LK, Wardman P, Czapski G, Goldstein S. Thiyl radicals react with nitric oxide to form S-nitrosothiols with rate constants near the diffusion-controlled limit.Free Radic Biol Med. 2008;44(12):20132018.

16. Jourd'heuil D, Jourd'heuil FL, Feelisch M. Oxidation and nitrosation of thiols at low micromolar exposure to nitric oxide. Evidence for a free radical mechanism. J Biol Chem. 2003;278(18):15720-15726. 
17. Marino SM, Gladyshev VN. Cysteine function governs its conservation and degeneration and restricts its utilization on protein surfaces. J Mol Biol. 2010;404(5):902-916.

18. Weerapana E, Wang C, Simon GM, et al. Quantitative reactivity profiling predicts functional cysteines in proteomes. Nature. 2010;468(7325):790-795.

19. Lima B, Forrester MT, Hess DT, Stamler JS. S-nitrosylation in cardiovascular signaling. Circ Res. 2010;106(4):633-646.

20. Nakashima H, Nishikawa K. Discrimination of intracellular and extracellular proteins using amino acid composition and residue-pair frequencies. J Mol Biol.1994;238(1):54-61.

21. Nakashima H, Nishikawa K. The amino acid composition is different between the cytoplasmic and extracellular sides in membrane proteins. FEBS Lett.1992;303(2-3):141-146.

22. Tu BP, Weissman JS. Oxidative protein folding in eukaryotes: mechanisms and consequences. J Cell Biol. 2004;164(3):341-346.

23. Go YM, Duong DM, Peng J, Jones DP. Protein Cysteines Map to Functional Networks According to Steady-state Level of Oxidation. Journal of proteomics \& bioinformatics. 2011;4(10):196-209.

24. Fomenko DE, Xing W, Adair BM, Thomas DJ, Gladyshev VN. High-throughput identification of catalytic redox-active cysteine residues. Science. 2007;315(5810):387-389.

25. Marozkina NV, Gaston B. S-Nitrosylation signaling regulates cellular protein interactions.Biochim Biophys Acta. 2012;1820(6):722-729.

26. Gow AJ, Chen Q, Hess DT, Day BJ, Ischiropoulos H, Stamler JS. Basal and stimulated protein Snitrosylation in multiple cell types and tissues. J Biol Chem.2002;277(12):9637-9640.

27. Furuta S. Basal S-Nitrosylation Is the Guardian of Tissue Homeostasis. Trends Cancer.2017;3(11):744748.

28. Nakamura T, Prikhodko OA, Pirie E, et al. Aberrant protein S-nitrosylation contributes to the pathophysiology of neurodegenerative diseases. Neurobiol Dis.2015;84:99-108.

29. Wadham C, Parker A, Wang L, Xia P. High glucose attenuates protein S-nitrosylation in endothelial cells: role of oxidative stress. Diabetes. 2007;56(11):2715-2721.

30. Tan C, Li Y, Huang X, et al. Extensive protein S-nitrosylation associated with human pancreatic ductal adenocarcinoma pathogenesis. Cell Death Dis.2019;10(12):914.

31. Wang Z. Protein S-nitrosylation and cancer. Cancer Lett. 2012;320(2):123-129.

32. Lipton SA, Choi YB, Takahashi H, et al. Cysteine regulation of protein function-as exemplified by NMDA-receptor modulation. Trends Neurosci. 2002;25(9):474-480.

33. Foster MW, Hess DT, Stamler JS. Protein S-nitrosylation in health and disease: a current perspective. Trends Mol Med. 2009;15(9):391-404.

34. Viner RI, Williams TD, Schoneich C. Peroxynitrite modification of protein thiols: oxidation, nitrosylation, and S-glutathiolation of functionally important cysteine residue(s) in the sarcoplasmic reticulum Ca-ATPase. Biochemistry.1999;38(38):12408-12415.

35. Smerjac SM, Bizzozero OA. Cytoskeletal protein carbonylation and degradation in experimental autoimmune encephalomyelitis. J Neurochem. 2008;105(3):763-772.

36. Sawa T, Zaki MH, Okamoto T, et al. Protein S-guanylation by the biological signal 8-nitroguanosine 3',5'-cyclic monophosphate. Nat Chem Biol. 2007;3(11):727-735. 
37. Paul BD, Snyder SH. H(2)S signalling through protein sulfhydration and beyond. Nat Rev Mol Cell Biol. 2012;13(8):499-507.

38. Lipton SA, Choi YB, Pan ZH, et al. A redox-based mechanism for the neuroprotective and neurodestructive effects of nitric oxide and related nitroso-compounds. Nature.1993;364(6438):626-632.

39. Haendeler J, Hoffmann J, Tischler V, Berk BC, Zeiher AM, Dimmeler S. Redox regulatory and antiapoptotic functions of thioredoxin depend on S-nitrosylation at cysteine 69. Nat Cell Biol. 2002;4(10):743-749.

40. Uehara T, Nakamura T, Yao D, et al. S-nitrosylated protein-disulphide isomerase links protein misfolding to neurodegeneration. Nature. 2006;441(7092):513-517.

41. Tegeder I, Scheving R, Wittig I, Geisslinger G. SNO-ing at the nociceptive synapse? Pharmacol Rev.2011;63(2):366-389.

42. Gaston BM, Carver J, Doctor A, Palmer LA. S-nitrosylation signaling in cell biology. Mol Interv.2003;3(5):253-263.

43. Gow AJ, Farkouh CR, Munson DA, Posencheg MA, Ischiropoulos H. Biological significance of nitric oxide-mediated protein modifications. Am J Physiol Lung Cell Mol Physiol. 2004;287(2):L262-268.

44. Liu L, Yan Y, Zeng M, et al. Essential roles of S-nitrosothiols in vascular homeostasis and endotoxic shock. Cell. 2004;116(4):617-628.

45. Hess DT, Matsumoto A, Kim SO, Marshall HE, Stamler JS. Protein S-nitrosylation: purview and parameters. Nat Rev Mol Cell Biol. 2005;6(2):150-166.

46. Greco TM, Hodara R, Parastatidis I, et al. Identification of S-nitrosylation motifs by site-specific mapping of the S-nitrosocysteine proteome in human vascular smooth muscle cells. Proc Natl Acad Sci U S A. 2006;103(19):7420-7425.

47. Stamler JS, Toone EJ, Lipton SA, Sucher NJ. (S)NO signals: translocation, regulation, and a consensus motif. Neuron. 1997;18(5):691-696.

48. Marino SM, Gladyshev VN. Structural analysis of cysteine S-nitrosylation: a modified acid-based motif and the emerging role of trans-nitrosylation. J Mol Biol.2010;395(4):844-859.

49. Chaki M, Kovacs I, Spannagl M, Lindermayr C. Computational prediction of candidate proteins for S-nitrosylation in Arabidopsis thaliana. PLoS One.2014;9(10):e110232.

50. Zaman K, Carraro S, Doherty J, et al. S-nitrosylating agents: a novel class of compounds that increase cystic fibrosis transmembrane conductance regulator expression and maturation in epithelial cells. Mol Pharmacol.2006;70(4):1435-1442.

51. Paige JS, Xu G, Stancevic B, Jaffrey SR. Nitrosothiol reactivity profiling identifies S-nitrosylated proteins with unexpected stability. Chem Biol.2008;15(12):1307-1316.

52. Khomyakov DG, Timerghazin QK. Toward reliable modeling of S-nitrosothiol chemistry: Structure and properties of methyl thionitrite (CH3SNO), an S-nitrosocysteine model.J Chem Phys. 2017;147(4):044305.

53. Meyer B, Genoni A, Boudier A, Leroy P, Ruiz-Lopez MF. Structure and Stability Studies of Pharmacologically Relevant S-Nitrosothiols: A Theoretical Approach.J Phys Chem A. 2016;120(24):4191-4200.

54. Gaston B, Drazen JM, Jansen A, et al. Relaxation of human bronchial smooth muscle by S-nitrosothiols in vitro. J Pharmacol Exp Ther. 1994;268(2):978-984.

55. Hogg N, Singh RJ, Konorev E, Joseph J, Kalyanaraman B. S-Nitrosoglutathione as a substrate for gamma-glutamyl transpeptidase. Biochem J. 1997;323 ( Pt 2):477-481.

56. Bryan NS, Calvert JW, Elrod JW, Gundewar S, Ji SY, Lefer DJ. Dietary nitrite supplementation protects against myocardial ischemia-reperfusion injury. Proc Natl Acad Sci U S A. 2007;104(48):19144-19149. 
57. Liu L, Hausladen A, Zeng M, et al. Nitrosative stress: protection by glutathione-dependent formaldehyde dehydrogenase. Redox Rep. 2001;6(4):209-210.

58. Liu L, Hausladen A, Zeng M, Que L, Heitman J, Stamler JS. A metabolic enzyme for S-nitrosothiol conserved from bacteria to humans. Nature.2001;410(6827):490-494.

59. Nakamura T, Lipton SA. Emerging role of protein-protein transnitrosylation in cell signaling pathways. Antioxid Redox Signal. 2013;18(3):239-249.

60. Gaston B, Reilly J, Drazen JM, et al. Endogenous nitrogen oxides and bronchodilator S-nitrosothiols in human airways. Proc Natl Acad Sci U S A. 1993;90(23):10957-10961.

61. Jensen DE, Belka GK, Du Bois GC. S-Nitrosoglutathione is a substrate for rat alcohol dehydrogenase class III isoenzyme. Biochem J. 1998;331 ( Pt 2):659-668.

62. Angelo M, Singel DJ, Stamler JS. An S-nitrosothiol (SNO) synthase function of hemoglobin that utilizes nitrite as a substrate. Proc Natl Acad Sci U S A.2006;103(22):8366-8371.

63. Benhar M, Forrester MT, Stamler JS. Protein denitrosylation: enzymatic mechanisms and cellular functions. Nat Rev Mol Cell Biol. 2009;10(10):721-732.

64. Lima B, Lam GK, Xie L, et al. Endogenous S-nitrosothiols protect against myocardial injury. Proc Natl Acad Sci U S A. 2009;106(15):6297-6302.

65. Bateman RL, Rauh D, Tavshanjian B, Shokat KM. Human carbonyl reductase 1 is an Snitrosoglutathione reductase. J Biol Chem. 2008;283(51):35756-35762.

66. Schulman IH, Hare JM. Regulation of cardiovascular cellular processes by S-nitrosylation. Biochim Biophys Acta. 2012;1820(6):752-762.

67. Das DK, Maulik N. Preconditioning potentiates redox signaling and converts death signal into survival signal. Arch Biochem Biophys. 2003;420(2):305-311.

68. Sengupta R, Ryter SW, Zuckerbraun BS, Tzeng E, Billiar TR, Stoyanovsky DA. Thioredoxin catalyzes the denitrosation of low-molecular mass and protein S-nitrosothiols.Biochemistry. 2007;46(28):8472-8483.

69. Stoyanovsky DA, Tyurina YY, Tyurin VA, et al. Thioredoxin and lipoic acid catalyze the denitrosation of low molecular weight and protein S-nitrosothiols. J Am Chem Soc. 2005;127(45):15815-15823.

70. Lillig CH, Holmgren A. Thioredoxin and related molecules-from biology to health and disease.Antioxid Redox Signal. 2007;9(1):25-47.

71. Benhar M, Forrester MT, Hess DT, Stamler JS. Regulated protein denitrosylation by cytosolic and mitochondrial thioredoxins. Science. 2008;320(5879):1050-1054.

72. Kneeshaw S, Spoel SH. Thioredoxin-Dependent Decomposition of Protein S-Nitrosothiols. Methods Mol Biol. 2018;1747:281-297.

73. Collet JF, Messens J. Structure, function, and mechanism of thioredoxin proteins. Antioxid Redox Signal. 2010;13(8):1205-1216.

74. Benhar M. Nitric oxide and the thioredoxin system: a complex interplay in redox regulation.Biochim Biophys Acta. 2015;1850(12):2476-2484.

75. Jeffrey Man HS, Tsui AK, Marsden PA. Nitric oxide and hypoxia signaling. Vitam Horm.2014;96:161192.

76. Treuer AV, Gonzalez DR. Nitric oxide synthases, S-nitrosylation and cardiovascular health: from molecular mechanisms to therapeutic opportunities (review). Mol Med Rep. 2015;11(3):1555-1565.

77. Go YM, Chandler JD, Jones DP. The cysteine proteome. Free Radic Biol Med. 2015;84:227-245. 
78. Villanueva C, Giulivi C. Subcellular and cellular locations of nitric oxide synthase isoforms as determinants of health and disease. Free Radic Biol Med.2010;49(3):307-316.

79. Xue Q, Yan Y, Zhang R, Xiong H. Regulation of iNOS on Immune Cells and Its Role in Diseases.International journal of molecular sciences. 2018;19(12).

80. Hoffmann A, Gloe T, Pohl U. Hypoxia-induced upregulation of eNOS gene expression is redox-sensitive: a comparison between hypoxia and inhibitors of cell metabolism. J Cell Physiol. 2001;188(1):33-44.

81. Shi Y, Baker JE, Zhang C, Tweddell JS, Su J, Pritchard KA, Jr. Chronic hypoxia increases endothelial nitric oxide synthase generation of nitric oxide by increasing heat shock protein 90 association and serine phosphorylation. Circ Res. 2002;91(4):300-306.

82. Kang TM. Unconventional eNOS in pulmonary artery smooth muscles: why should it be there? Pflugers Arch. 2019;471(10):1245-1246.

83. Kluge I, Gutteck-Amsler U, Zollinger M, Do KQ. S-nitrosoglutathione in rat cerebellum: identification and quantification by liquid chromatography-mass spectrometry. J Neurochem. 1997;69(6):2599-2607.

84. Mannick JB, Schonhoff C, Papeta N, et al. S-Nitrosylation of mitochondrial caspases. $J$ Cell Biol.2001;154(6):1111-1116.

85. Zhang Y, Hogg N. Formation and stability of S-nitrosothiols in RAW 264.7 cells. Am J Physiol Lung Cell Mol Physiol. 2004;287(3):L467-474.

86. Griffiths C, Garthwaite J. The shaping of nitric oxide signals by a cellular sink. J Physiol.2001;536(Pt $3): 855-862$.

87. Gow AJ, Ischiropoulos H. Nitric oxide chemistry and cellular signaling. J Cell Physiol.2001;187(3):277282.

88. Kim SF, Huri DA, Snyder SH. Inducible nitric oxide synthase binds, S-nitrosylates, and activates cyclooxygenase-2. Science. 2005;310(5756):1966-1970.

89. Stamler JS, Lamas S, Fang FC. Nitrosylation. the prototypic redox-based signaling mechanism. Cell. 2001;106(6):675-683.

90. Erwin PA, Mitchell DA, Sartoretto J, Marletta MA, Michel T. Subcellular targeting and differential S-nitrosylation of endothelial nitric-oxide synthase. J Biol Chem. 2006;281(1):151-157.

91. Erwin PA, Lin AJ, Golan DE, Michel T. Receptor-regulated dynamic S-nitrosylation of endothelial nitric-oxide synthase in vascular endothelial cells. J Biol Chem.2005;280(20):19888-19894.

92. Martinez-Ruiz A, Villanueva L, Gonzalez de Orduna C, et al. S-nitrosylation of Hsp90 promotes the inhibition of its ATPase and endothelial nitric oxide synthase regulatory activities. Proc Natl Acad Sci US A.2005;102(24):8525-8530.

93. Fang M, Jaffrey SR, Sawa A, Ye K, Luo X, Snyder SH. Dexras1: a G protein specifically coupled to neuronal nitric oxide synthase via CAPON. Neuron. 2000;28(1):183-193.

94. Fulton D, Fontana J, Sowa G, et al. Localization of endothelial nitric-oxide synthase phosphorylated on serine 1179 and nitric oxide in Golgi and plasma membrane defines the existence of two pools of active enzyme. J Biol Chem.2002;277(6):4277-4284.

95. Iwakiri Y. S-nitrosylation of proteins: a new insight into endothelial cell function regulated by eNOSderived NO. Nitric oxide : biology and chemistry.2011;25(2):95-101.

96. Iwakiri Y, Satoh A, Chatterjee S, et al. Nitric oxide synthase generates nitric oxide locally to regulate compartmentalized protein S-nitrosylation and protein trafficking.Proc Natl Acad Sci U S A. 2006;103(52):19777-19782. 
97. Jagnandan D, Sessa WC, Fulton D. Intracellular location regulates calcium-calmodulin-dependent activation of organelle-restricted eNOS. Am J Physiol Cell Physiol.2005;289(4):C1024-1033.

98. Fulton D, Babbitt R, Zoellner S, et al. Targeting of endothelial nitric-oxide synthase to the cytoplasmic face of the Golgi complex or plasma membrane regulates Akt- versus calcium-dependent mechanisms for nitric oxide release. J Biol Chem. 2004;279(29):30349-30357.

99. Su Y, Kondrikov D, Block ER. Cytoskeletal regulation of nitric oxide synthase. Cell Biochem Biophys. 2005;43(3):439-449.

100. Stomberski CT, Hess DT, Stamler JS. Protein S-Nitrosylation: Determinants of Specificity and Enzymatic Regulation of S-Nitrosothiol-Based Signaling. Antioxid Redox Signal. 2019;30(10):1331-1351.

101. Chen Z, Zhang J, Stamler JS. Identification of the enzymatic mechanism of nitroglycerin bioactivation. Proc Natl Acad Sci U S A. 2002;99(12):8306-8311.

102. van Faassen EE, Bahrami S, Feelisch M, et al. Nitrite as regulator of hypoxic signaling in mammalian physiology. Med Res Rev. 2009;29(5):683-741.

103. Jones JA, Ninnis JR, Hopper AO, et al. Nitrite and nitrate concentrations and metabolism in breast milk, infant formula, and parenteral nutrition. JPEN J Parenter Enteral Nutr. 2014;38(7):856-866.

104. Ibrahim YI, Ninnis JR, Hopper AO, et al. Inhaled nitric oxide therapy increases blood nitrite, nitrate, and s-nitrosohemoglobin concentrations in infants with pulmonary hypertension. J Pediatr. 2012;160(2):245251.

105. Moya MP, Gow AJ, Califf RM, Goldberg RN, Stamler JS. Inhaled ethyl nitrite gas for persistent pulmonary hypertension of the newborn. Lancet.2002;360(9327):141-143.

106. Auten RL, Mason SN, Whorton MH, et al. Inhaled ethyl nitrite prevents hyperoxia-impaired postnatal alveolar development in newborn rats. Am J Respir Crit Care Med.2007;176(3):291-299.

107. Baliga RS, Milsom AB, Ghosh SM, et al. Dietary nitrate ameliorates pulmonary hypertension: cytoprotective role for endothelial nitric oxide synthase and xanthine oxidoreductase. Circulation. 2012;125(23):2922-2932.

108. Zuckerbraun BS, George P, Gladwin MT. Nitrite in pulmonary arterial hypertension: therapeutic avenues in the setting of dysregulated arginine/nitric oxide synthase signalling. Cardiovasc Res. 2011;89(3):542-552.

109. Yingchoncharoen T, Rakyhao T, Chuncharunee S, et al. Inhaled nebulized sodium nitrite decreases pulmonary artery pressure in beta-thalassemia patients with pulmonary hypertension. Nitric Oxide. 2018;76:174-178.

110. Jankov RP, Daniel KL, Iny S, et al. Sodium nitrite augments lung S-nitrosylation and reverses chronic hypoxic pulmonary hypertension in juvenile rats. Am J Physiol Lung Cell Mol Physiol. 2018;315(5):L742L751.

111. Bryan NS, Fernandez BO, Bauer SM, et al. Nitrite is a signaling molecule and regulator of gene expression in mammalian tissues. Nat Chem Biol.2005;1(5):290-297.

112. Dalsgaard T, Simonsen U, Fago A. Nitrite-dependent vasodilation is facilitated by hypoxia and is independent of known NO-generating nitrite reductase activities.Am J Physiol Heart Circ Physiol. 2007;292(6):H3072-3078.

113. Dezfulian C, Raat N, Shiva S, Gladwin MT. Role of the anion nitrite in ischemia-reperfusion cytoprotection and therapeutics. Cardiovasc Res.2007;75(2):327-338.

114. Egemnazarov B, Schermuly RT, Dahal BK, et al. Nebulization of the acidified sodium nitrite formulation attenuates acute hypoxic pulmonary vasoconstriction. Respir Res. 2010;11:81. 
115. Torok JA, Brahmajothi MV, Zhu H, Tinch BT, Auten RL, McMahon TJ. Transpulmonary flux of S-nitrosothiols and pulmonary vasodilation during nitric oxide inhalation: role of transport. Am J Respir Cell Mol Biol.2012;47(1):37-43.

116. Weinberger B, Laskin DL, Heck DE, Laskin JD. The toxicology of inhaled nitric oxide. Toxicol Sci. 2001;59(1):5-16.

117. Foubert L, Fleming B, Latimer R, et al. Safety guidelines for use of nitric oxide. Lancet.1992;339(8809):1615-1616.

118. Totapally BR, Raszynski A, Sussmane J, et al. Nitric oxide and nitrogen dioxide concentrations during in vitro high-frequency oscillatory ventilation. J Crit Care. 1999;14(3):141-149.

119. Radi R. Protein tyrosine nitration: biochemical mechanisms and structural basis of functional effects. Accounts of chemical research. 2013;46(2):550-559.

120. Jankov RP, Johnstone L, Luo X, Robinson BH, Tanswell AK. Macrophages as a major source of oxygen radicals in the hyperoxic newborn rat lung. Free Radic Biol Med.2003;35(2):200-209.

121. Lorch SA, Munson D, Lightfoot RT, Ischiropoulos H. Oxygen tension and inhaled nitric oxide modulate pulmonary levels of S-nitrosocysteine and 3-nitrotyrosine in rats.Pediatr Res. 2004;56(3):345-352.

122. Stenger MR, Rose MJ, Joshi MS, et al. Inhaled nitric oxide prevents 3-nitrotyrosine formation in the lungs of neonatal mice exposed to $>95 \%$ oxygen.Lung. 2010;188(3):217-227.

123. Nelin LD, Welty SE, Morrisey JF, Gotuaco C, Dawson CA. Nitric oxide increases the survival of rats with a high oxygen exposure. Pediatr Res. 1998;43(6):727-732.

124. Robbins CG, Horowitz S, Merritt TA, et al. Recombinant human superoxide dismutase reduces lung injury caused by inhaled nitric oxide and hyperoxia. Am J Physiol.1997;272(5 Pt 1):L903-907.

125. Lorch SA, Foust R, 3rd, Gow A, et al. Immunohistochemical localization of protein 3-nitrotyrosine and S-nitrosocysteine in a murine model of inhaled nitric oxide therapy.Pediatr Res. 2000;47(6):798-805.

126. Wink DA, Nims RW, Darbyshire JF, et al. Reaction kinetics for nitrosation of cysteine and glutathione in aerobic nitric oxide solutions at neutral $\mathrm{pH}$. Insights into the fate and physiological effects of intermediates generated in the NO/O2 reaction. Chem Res Toxicol. 1994;7(4):519-525.

127. Espey MG, Thomas DD, Miranda KM, Wink DA. Focusing of nitric oxide mediated nitrosation and oxidative nitrosylation as a consequence of reaction with superoxide. Proc Natl Acad Sci U S A. 2002;99(17):11127-11132.

128. Mayer B, Pfeiffer S, Schrammel A, Koesling D, Schmidt K, Brunner F. A new pathway of nitric oxide/cyclic GMP signaling involving S-nitrosoglutathione. J Biol Chem. 1998;273(6):3264-3270.

129. Schrammel A, Gorren AC, Schmidt K, Pfeiffer S, Mayer B. S-nitrosation of glutathione by nitric oxide, peroxynitrite, and $\left(^{*}\right) \mathrm{NO} / \mathrm{O}(2)\left(*_{-}\right)$. Free Radic Biol Med.2003;34(8):1078-1088.

130. Rubbo H, Radi R, Trujillo M, et al. Nitric oxide regulation of superoxide and peroxynitritedependent lipid peroxidation. Formation of novel nitrogen-containing oxidized lipid derivatives. $J$ Biol Chem. 1994;269(42):26066-26075.

131. Moller MN, Cuevasanta E, Orrico F, Lopez AC, Thomson L, Denicola A. Diffusion and Transport of Reactive Species Across Cell Membranes. Adv Exp Med Biol. 2019;1127:3-19.

132. Gore A, Muralidhar M, Espey MG, Degenhardt K, Mantell LL. Hyperoxia sensing: from molecular mechanisms to significance in disease. Journal of immunotoxicology.2010;7(4):239-254.

133. Jaitovich A, Jourd'heuil D. A Brief Overview of Nitric Oxide and Reactive Oxygen Species Signaling in Hypoxia-Induced Pulmonary Hypertension. Adv Exp Med Biol.2017;967:71-81. 
134. Gong Y, Yi M, Fediuk J, Lizotte PP, Dakshinamurti S. Hypoxic neonatal pulmonary arterial myocytes are sensitized to ROS-generated 8-isoprostane. Free Radic Biol Med.2010;48(7):882-894.

135. Smith KA, Waypa GB, Schumacker PT. Redox signaling during hypoxia in mammalian cells. Redox biology. 2017;13:228-234.

136. Chen SC, Huang B, Liu YC, Shyu KG, Lin PY, Wang DL. Acute hypoxia enhances proteins' Snitrosylation in endothelial cells. Biochem Biophys Res Commun.2008;377(4):1274-1278.

137. Chavez MD, Lakshmanan N, Kavdia M. Impact of superoxide dismutase on nitric oxide and peroxynitrite levels in the microcirculation-a computational model.Conference proceedings : Annual International Conference of the IEEE Engineering in Medicine and Biology Society IEEE Engineering in Medicine and Biology Society Annual Conference. 2007;2007:1022-1026.

138. McMahon TJ, Moon RE, Luschinger BP, et al. Nitric oxide in the human respiratory cycle. Nature medicine. 2002;8(7):711-717.

139. Cosby K, Partovi KS, Crawford JH, et al. Nitrite reduction to nitric oxide by deoxyhemoglobin vasodilates the human circulation. Nature medicine.2003;9(12):1498-1505.

140. Allen BW, Stamler JS, Piantadosi CA. Hemoglobin, nitric oxide and molecular mechanisms of hypoxic vasodilation. Trends in molecular medicine.2009;15(10):452-460.

141. Gladwin MT. How Red Blood Cells Process Nitric Oxide: Evidence for the Nitrite Hypothesis. Circulation. 2017;135(2):177-179.

142. Inoue K, Akaike T, Miyamoto Y, et al. Nitrosothiol formation catalyzed by ceruloplasmin. Implication for cytoprotective mechanism in vivo. J Biol Chem.1999;274(38):27069-27075.

143. van Gils AP, Falke TH, van Erkel AR, et al. MR imaging and MIBG scintigraphy of pheochromocytomas and extraadrenal functioning paragangliomas. Radiographics.1991;11(1):37-57.

144. Broniowska KA, Diers AR, Hogg N. S-nitrosoglutathione. Biochim Biophys Acta.2013;1830(5):31733181 .

145. Zhang Y, Hogg N. The mechanism of transmembrane S-nitrosothiol transport. Proc Natl Acad Sci U $S$ A. 2004;101(21):7891-7896.

146. Davisson RL, Travis MD, Bates JN, Lewis SJ. Hemodynamic effects of L- and D-S-nitrosocysteine in the rat. Stereoselective S-nitrosothiol recognition sites. Circ Res.1996;79(2):256-262.

147. Hoque A, Bates JN, Lewis SJ. In vivo evidence that L-S-nitrosocysteine may exert its vasodilator effects by interaction with thiol residues in the vasculature. Eur J Pharmacol. 1999;384(2-3):169-172.

148. Filipovic MR, Miljkovic J, Nauser T, et al. Chemical characterization of the smallest S-nitrosothiol, HSNO; cellular cross-talk of H2S and S-nitrosothiols.J Am Chem Soc. 2012;134(29):12016-12027.

149. Lipton AJ, Johnson MA, Macdonald T, Lieberman MW, Gozal D, Gaston B. S-nitrosothiols signal the ventilatory response to hypoxia. Nature. 2001;413(6852):171-174.

150. Stamler JS, Jia L, Eu JP, et al. Blood flow regulation by S-nitrosohemoglobin in the physiological oxygen gradient. Science. 1997;276(5321):2034-2037.

151. Shiva S, Huang Z, Grubina R, et al. Deoxymyoglobin is a nitrite reductase that generates nitric oxide and regulates mitochondrial respiration. Circ Res.2007;100(5):654-661.

152. Shiva S, Wang X, Ringwood LA, et al. Ceruloplasmin is a NO oxidase and nitrite synthase that determines endocrine NO homeostasis. Nature chemical biology.2006;2(9):486-493.

153. Isbell TS, Sun CW, Wu LC, et al. SNO-hemoglobin is not essential for red blood cell-dependent hypoxic vasodilation. Nature medicine. 2008;14(7):773-777. 
154. Zuckerbraun BS, Shiva S, Ifedigbo E, et al. Nitrite potently inhibits hypoxic and inflammatory pulmonary arterial hypertension and smooth muscle proliferation via xanthine oxidoreductase-dependent nitric oxide generation. Circulation. 2010;121(1):98-109.

155. Simon MA, Vanderpool RR, Nouraie M, et al. Acute hemodynamic effects of inhaled sodium nitrite in pulmonary hypertension associated with heart failure with preserved ejection fraction. JCI insight. 2016;1(18):e89620.

156. Lauer T, Preik M, Rassaf T, et al. Plasma nitrite rather than nitrate reflects regional endothelial nitric oxide synthase activity but lacks intrinsic vasodilator action.Proc Natl Acad Sci U S A. 2001;98(22):1281412819.

157. Premont RT, Reynolds JD, Zhang R, Stamler JS. Role of Nitric Oxide Carried by Hemoglobin in Cardiovascular Physiology: Developments on a Three-Gas Respiratory Cycle. Circ Res. 2020;126(1):129158.

158. Reynolds JD, Hess DT, Stamler JS. The transfusion problem: role of aberrant Snitrosylation. Transfusion. 2011;51(4):852-858.

159. McMahon TJ, Ahearn GS, Moya MP, et al. A nitric oxide processing defect of red blood cells created by hypoxia: deficiency of S-nitrosohemoglobin in pulmonary hypertension.Proc Natl Acad Sci U S A. 2005;102(41):14801-14806.

160. Moya MP, Gow AJ, McMahon TJ, et al. S-nitrosothiol repletion by an inhaled gas regulates pulmonary function. Proc Natl Acad Sci U S A. 2001;98(10):5792-5797.

161. Gow AJ, Luchsinger BP, Pawloski JR, Singel DJ, Stamler JS. The oxyhemoglobin reaction of nitric oxide.Proc Natl Acad Sci U S A. 1999;96(16):9027-9032.

162. Jia L, Bonaventura C, Bonaventura J, Stamler JS. S-nitrosohaemoglobin: a dynamic activity of blood involved in vascular control. Nature.1996;380(6571):221-226.

163. Gow AJ, Stamler JS. Reactions between nitric oxide and haemoglobin under physiological conditions. Nature. 1998;391(6663):169-173.

164. Selemidis S, Dusting GJ, Peshavariya H, Kemp-Harper BK, Drummond GR. Nitric oxide suppresses NADPH oxidase-dependent superoxide production by S-nitrosylation in human endothelial cells. Cardiovasc Res. 2007;75(2):349-358.

165. Kim JH, Bugaj LJ, Oh YJ, et al. Arginase inhibition restores NOS coupling and reverses endothelial dysfunction and vascular stiffness in old rats. J Appl Physiol (1985). 2009;107(4):1249-1257.

166. Whalen EJ, Foster MW, Matsumoto A, et al. Regulation of beta-adrenergic receptor signaling by S-nitrosylation of G-protein-coupled receptor kinase 2. Cell.2007;129(3):511-522.

167. Wang G, Moniri NH, Ozawa K, Stamler JS, Daaka Y. Nitric oxide regulates endocytosis by Snitrosylation of dynamin. Proc Natl Acad Sci U S A.2006;103(5):1295-1300.

168. Stamler JS, Simon DI, Jaraki O, et al. S-nitrosylation of tissue-type plasminogen activator confers vasodilatory and antiplatelet properties on the enzyme. Proc Natl Acad Sci U S A. 1992;89(17):8087-8091.

169. Delyani JA, Nossuli TO, Scalia R, Thomas G, Garvey DS, Lefer AM. S-nitrosylated tissue-type plasminogen activator protects against myocardial ischemia/reperfusion injury in cats: role of the endothelium. J Pharmacol Exp Ther.1996;279(3):1174-1180.

170. Tang JR, Seedorf G, Balasubramaniam V, Maxey A, Markham N, Abman SH. Early inhaled nitric oxide treatment decreases apoptosis of endothelial cells in neonatal rat lungs after vascular endothelial growth factor inhibition. American journal of physiologyLung cellular and molecular physiology. 2007;293(5):L12711280 . 
171. ter Horst SA, Walther FJ, Poorthuis BJ, Hiemstra PS, Wagenaar GT. Inhaled nitric oxide attenuates pulmonary inflammation and fibrin deposition and prolongs survival in neonatal hyperoxic lung injury. $A m$ J Physiol Lung Cell Mol Physiol. 2007;293(1):L35-44.

172. Benedet PO, Menegatti ACO, Goncalves MC, Terenzi H, Assreuy J. The therapeutic value of protein (de)nitrosylation in experimental septic shock. Biochimica et biophysica acta Molecular basis of disease. 2018;1864(1):307-316.

173. Sips PY, Irie T, Zou L, et al. Reduction of cardiomyocyte S-nitrosylation by S-nitrosoglutathione reductase protects against sepsis-induced myocardial depression.Am J Physiol Heart Circ Physiol. 2013;304(8):H1134-1146.

174. Pei DS, Sun YF, Song YJ. S-nitrosylation of PTEN Invovled in ischemic brain injury in rat hippocampal CA1 region. Neurochem Res. 2009;34(8):1507-1512.

175. Ravi K, Brennan LA, Levic S, Ross PA, Black SM. S-nitrosylation of endothelial nitric oxide synthase is associated with monomerization and decreased enzyme activity.Proc Natl Acad Sci U S A. 2004;101(8):26192624 .

176. Brahmajothi MV, Tinch BT, Wempe MF, Endou H, Auten RL. Hyperoxia inhibits nitric oxide treatment effects in alveolar epithelial cells via effects on L-type amino acid transporter-1. Antioxid Redox Signal. 2014;21(13):1823-1836.

177. Guo CJ, Atochina-Vasserman EN, Abramova E, et al. S-nitrosylation of surfactant protein-D controls inflammatory function. PLoS biology. 2008;6(11):e266.

178. Song W, Liu G, Bosworth CA, et al. Respiratory syncytial virus inhibits lung epithelial Na+ channels by up-regulating inducible nitric-oxide synthase. J Biol Chem.2009;284(11):7294-7306.

179. Lin L, Xu C, Carraway MS, Piantadosi CA, Whorton AR, Li S. RhoA inactivation by S-nitrosylation regulates vascular smooth muscle contractive signaling. Nitric oxide : biology and chemistry. 2018;74:56-64.

180. Beuve A. Thiol-Based Redox Modulation of Soluble Guanylyl Cyclase, the Nitric Oxide Receptor.Antioxid Redox Signal. 2017;26(3):137-149.

181. Ghosh A, Stasch JP, Papapetropoulos A, Stuehr DJ. Nitric oxide and heat shock protein 90 activate soluble guanylate cyclase by driving rapid change in its subunit interactions and heme content. $J$ Biol Chem.2014;289(22):15259-15271.

182. Sayed N, Baskaran P, Ma X, van den Akker F, Beuve A. Desensitization of soluble guanylyl cyclase, the NO receptor, by S-nitrosylation. Proc Natl Acad Sci U S A.2007;104(30):12312-12317.

183. Crassous PA, Couloubaly S, Huang C, et al. Soluble guanylyl cyclase is a target of angiotensin II-induced nitrosative stress in a hypertensive rat model. Am J Physiol Heart Circ Physiol. 2012;303(5):H597-604.

184. Gladwin MT. Deconstructing endothelial dysfunction: soluble guanylyl cyclase oxidation and the NO resistance syndrome. J Clin Invest. 2006;116(9):2330-2332.

185. Sayed N, Kim DD, Fioramonti X, Iwahashi T, Duran WN, Beuve A. Nitroglycerin-induced Snitrosylation and desensitization of soluble guanylyl cyclase contribute to nitrate tolerance. Circ Res. 2008;103(6):606-614.

186. Evgenov OV, Pacher P, Schmidt PM, Hasko G, Schmidt HH, Stasch JP. NO-independent stimulators and activators of soluble guanylate cyclase: discovery and therapeutic potential. Nature reviews Drug discovery. 2006;5(9):755-768.

187. Kokkola T, Savinainen JR, Monkkonen KS, Retamal MD, Laitinen JT. S-nitrosothiols modulate G protein-coupled receptor signaling in a reversible and highly receptor-specific manner. BMC cell biology. 2005;6(1):21. 
188. Choi H, Tostes RC, Webb RC. Thioredoxin reductase inhibition reduces relaxation by increasing oxidative stress and s-nitrosylation in mouse aorta. J Cardiovasc Pharmacol. 2011;58(5):522-527.

189. Choi H, Allahdadi KJ, Tostes RC, Webb RC. Augmented S-nitrosylation contributes to impaired relaxation in angiotensin II hypertensive mouse aorta: role of thioredoxin reductase. $J$ Hypertens. 2011;29(12):2359-2368.

190. Ghosh A, Koziol-White CJ, Asosingh K, et al. Soluble guanylate cyclase as an alternative target for bronchodilator therapy in asthma. Proc Natl Acad Sci U S A.2016;113(17):E2355-2362.

191. Martin F, Baskaran P, Ma X, et al. Structure of cinaciguat (BAY 58-2667) bound to Nostoc HNOX domain reveals insights into heme-mimetic activation of the soluble guanylyl cyclase. J Biol Chem. 2010;285(29):22651-22657.

192. Kumar V, Martin F, Hahn MG, et al. Insights into BAY 60-2770 activation and S-nitrosylationdependent desensitization of soluble guanylyl cyclase via crystal structures of homologous nostoc H-NOX domain complexes. Biochemistry.2013;52(20):3601-3608.

193. Ghofrani HA, Humbert M, Langleben D, et al. Riociguat: Mode of Action and Clinical Development in Pulmonary Hypertension. Chest. 2017;151(2):468-480.

194. Sikarwar AS, Hinton M, Santhosh KT, et al. Hypoxia inhibits adenylyl cyclase catalytic activity in a porcine model of persistent pulmonary hypertension of the newborn. Am J Physiol Lung Cell Mol Physiol. 2018;315(6):L933-L944.

195. Jaggupilli A, Dhanaraj P, Pritchard A, Sorensen JL, Dakshinamurti S, Chelikani P. Study of adenylyl cyclase-GalphaS interactions and identification of novel AC ligands. Mol Cell Biochem. 2018;446:63-72.

Figure Legends

Figure 1: Reactive species generated from nitric oxide, and post-translational modifications

NO can gain electrons to become nitroxyl anion or lose electrons to become nitroso cation; oxidize to nitrite or nitrate; or further oxidize to nitrogen dioxide or dinitrogen trioxide. Cysteines sensitive to nitrosylation are flanked by "SNO motifs" containing basic and acidic residues. Nitroso ion, nitrite, and NO when in presence of superoxide, can react spontaneously with cysteine thiols to form nitrosocysteine. Nitrogen dioxide reacts with cysteine to produce thiyl radical, which reacts with peroxynitrite to make nitrosocysteine. In a competing reaction, peroxynitrite reacts with the aromatic ring of tyrosine to form 3-nitrotyrosine.

Figure 2: Transnitrosylation and denitrosylation mechanisms of protein S-nitrosothiols (RSNO)

Nitric oxide synthase (NOS) produces NO $[\mathbf{A}]$, resulting in auto-nitrosylation of NOS. NO oxidizes to nitrogen oxide (NOx) species including $\mathrm{NO}_{2}$ and $\mathrm{N}_{2} \mathrm{O}_{3}$ that can convert glutathione (GSH) to S-nitrosoglutathione (GSNO). [B ] GSNO can be generated via the transition metal pathway, where NO reacts with metalcontaining proteins to form R-SNOH; the thiyl radical pathway, where $\mathrm{NO}_{2}$ reacts with a thiol to produce a thiyl radical (R-S. ); the NO oxidation pathway where $\mathrm{N}_{2} \mathrm{O}_{3}$ reacts directly with a thiol to form R-SNO; or by transnitrosation from R-SNO, such as the nitrosylated NOS. [C ] Denitrosylation of GSNO leading to formation of non-bioavailable NO requires its reduction by nitrosoglutathione reductase (GSNOR) to intermediate GSNHOH, which reacts with GSH to produce glutathione disulfide (GSSG) and $\mathrm{NH}_{2} \mathrm{OH}$, later reduced by glutathione reductase (GR) to remake GSH; or GSNHOH hydrolysis to $\mathrm{GSO}_{2} \mathrm{H}$ and ammonia. [D ] Denitrosylation of any other R-SNO requires transnitrosylation of thioredoxin (Trx) to one of its acceptor cysteines ( $\mathrm{X}$ indicating cysteine position). Thioredoxin is then restored by thioredoxin reductase (TrxR).

Figure 3: Nitric oxide sources, hypoxic vasodilation and vasoconstriction

Nitrite $\left(\mathrm{NO}_{2}{ }^{-}\right)$can be endogenous or arise from nitrite donors such as ethyl nitrite $\left(\mathrm{C}_{2} \mathrm{H}_{5} \mathrm{NO}_{2}\right)$ or other $\mathrm{RNO}_{2}$, sodium nitrite $\left(\mathrm{NaNO}_{2}\right)$ or nitrate; it is reduced to NO by xanthine oxidoreductase (XOR). In- 
haled nitric oxide (iNO) is an exogenous source of NO. NO generates nitrosothiols (SNO) proteins directly through oxidation and conversion, by rapid combination with superoxide $\left(\mathrm{O}_{2}{ }^{-}\right)$, or through $\mathrm{NO}$ reaction with superoxide to form peroxynitrite (ONOO-). Vasodilator effects of SNO formation include nitrosylation of hemoglobin ( $\mathrm{Hb}$ ) to form SNO-Hb (nitrosohemoglobin), delivering NO to the distal circulation. Glutathione (GSH) nitrosylation can deliver SNO locally to transnitrosylate other proteins. Soluble guanylate cyclase (sGC) is the intracellular receptor of NO, generating cyclic GMP important for arterial relaxation, particularly in the pulmonary circuit. Vasoconstrictor effects of SNO formation include nitrosylation of sGC, inhibiting vasodilation.

Figure 1

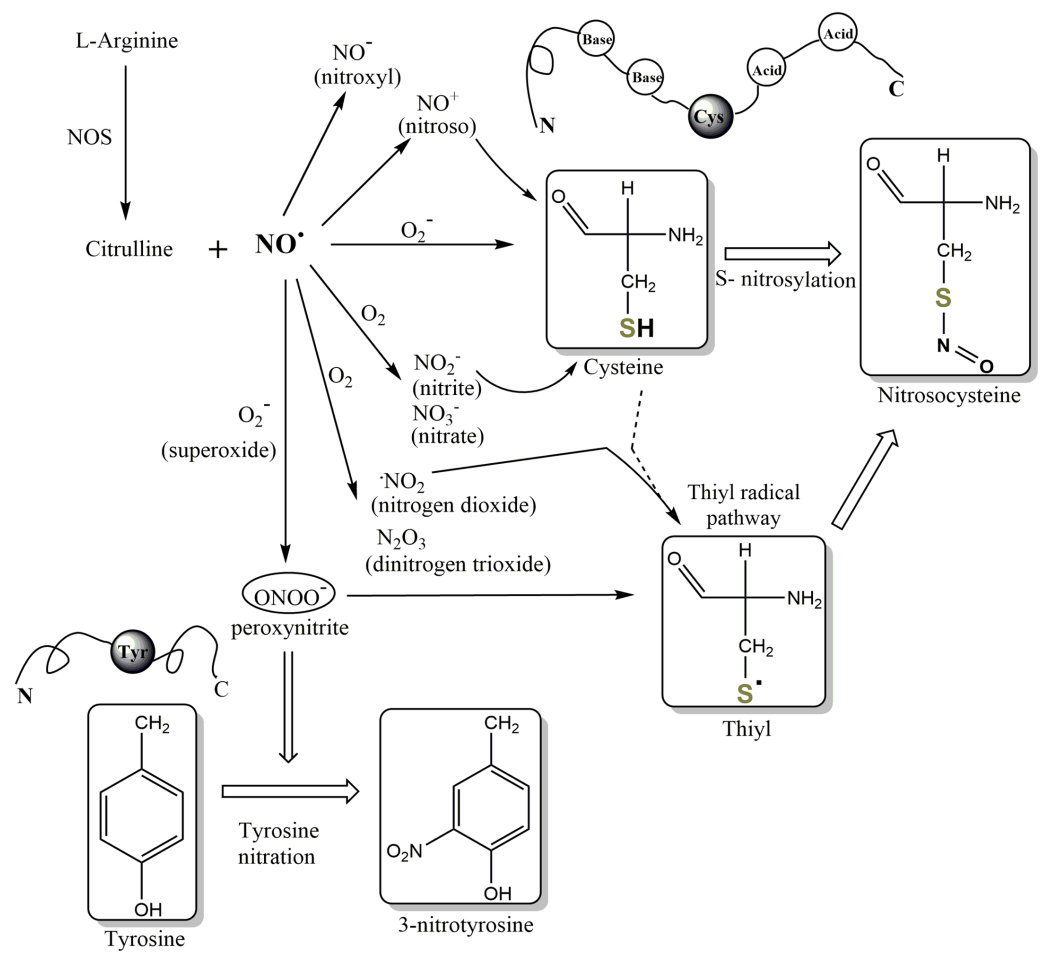


Figure 2

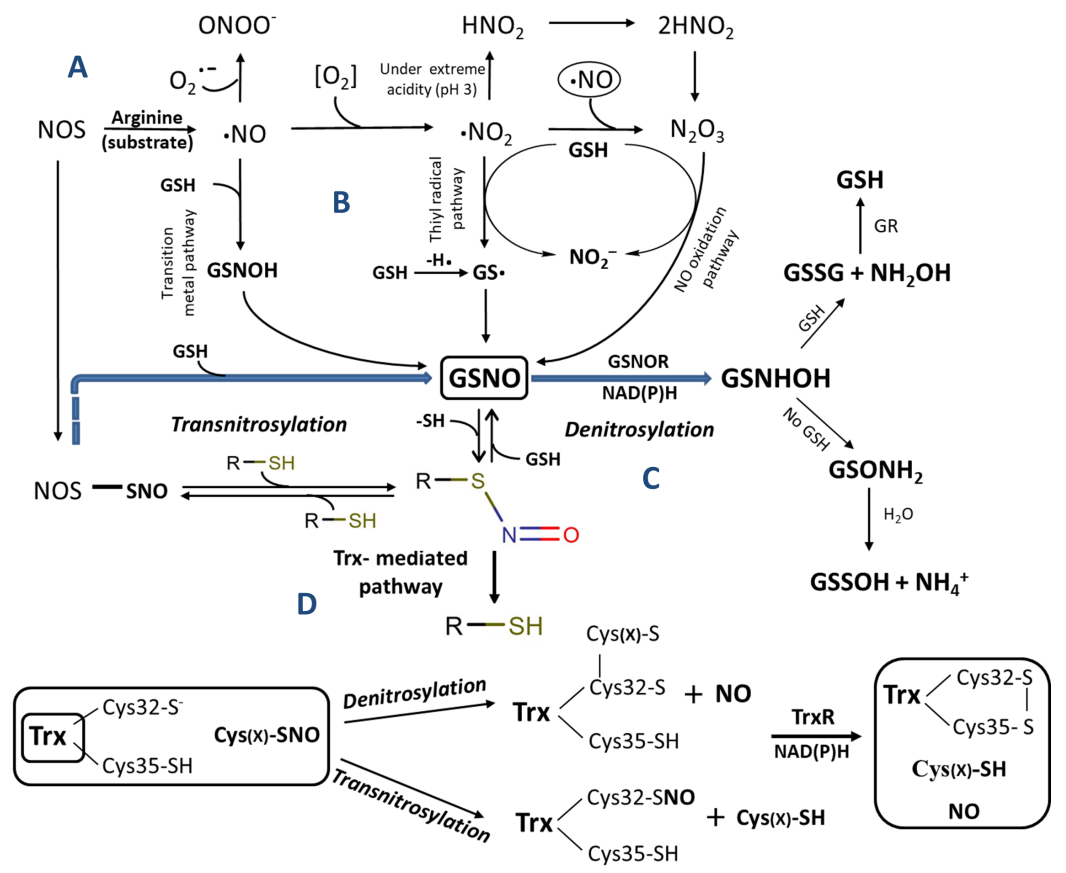

Figure 3

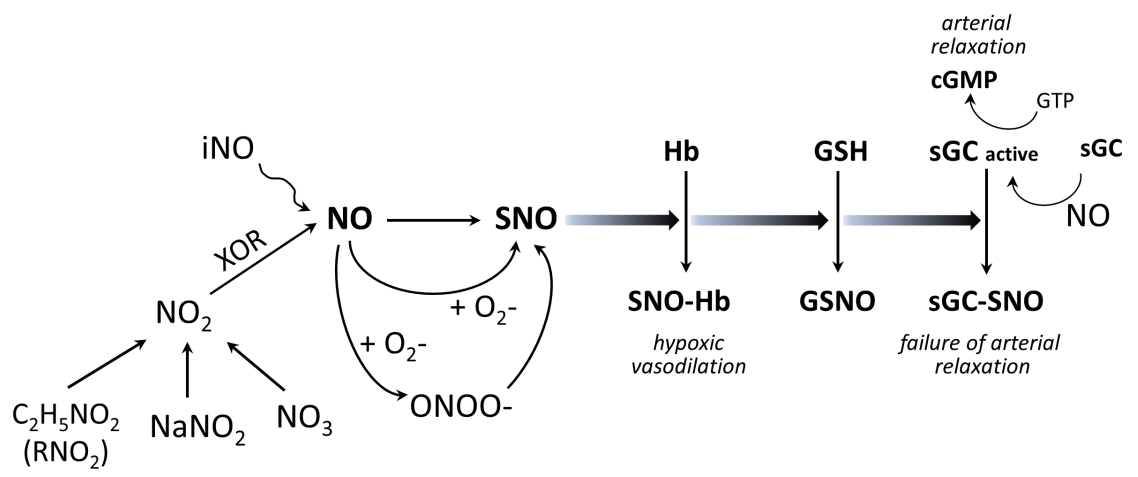

